\title{
Rancang Bangun Instrument Untuk Mengukur Gaya Potong, Kecepatan, Dan Temperatur Spesimen Pada Mesin Bubut
}

\section{Instrument Design To Measure Cut Style, Speed, And Specimen Temperature On Machine Tool}

\author{
Khairul Umurani ${ }^{1)} *$ \\ 1) Prodi Mesin, Fakultas Teknik, Universitas Muhammadiyah Sumatera Utara, Indonesia \\ *Coresponding Email:
}

\section{Abstrak}

Proses pengerjaan atau pembuatan komponen-komponen pada mesin- mesin, tidak lepas dari pada mesin-mesin produksi seperti mesin bubut.Mesin bubut banyak digunakan pada industri maupun laboratorium namun tidak banyak mesin bubut yang menggunakan instrument untuk mengukur parameter pembubutan.Pengaruh pahat potong, material benda kerja, dan kondisi pemotongan (kecepatan potong, kedalam potong dan gerak makan) terhadap keausan pahat bubut. Kecepatan potong (cutting speed) tidak dapat dipilih sembarangan karena akan mempengaruhi kualitas produk dan biaya. Konsep desain dilakukan terlebih dahulu dengan mempersiapkan loadcell dan pahat kemudian merekayasabentuk dudukan loadcell dan pahat yang akan dibuat dengan menggambar manual diatas kertas. Pada proses pembuatan alat instrument mesin bubut ini terbagi menjadi dua kelompok yaitu, pembuatan alat dan rangkaian sensor-sensor yang diperlukan.Instrument ini mampu mengukur gaya potong, kecepatan dan temperature spesimen pada proses pembubutan yang sedang berlangsung secara bersamaan.

Kata Kunci: Parameter pembubutan, instrument, konsep desain dan pembuatan

\begin{abstract}
Process workmanship or manufacture of components on the machines, not separated from the production machines such as lathe. Lathe machines are widely used in industry and laboratory but not many lathe that use instrument to measure parameters pemubutan.Pengaruh chisel cut, material workpiece, and cutting conditions (cutting speed, cutting and feeding) on lathe tool wear. Cutting speed (cutting speed) can not be chosen carelessly because it will affect product quality and cost. The design concept is done first by preparing the loadcell and the chisel then they form the loadcell holder and the chisel will be created by drawing the manual on paper. In the process of making the instrument instrument lathe is divided into two groups, namely, making tools and series of sensors needed. This instrument is able to measure the cutting force, speed and temperature of the specimen in the process of lathing is simultaneously.
\end{abstract}

\section{Keywords: Parameters of lathe, instrument, concept of design and manufacture}

How to Cite: Umurani, K (2017). Rancang Bangun Instrument Untuk Mengukur Gaya Potong, Kecepatan, Dan Temperatur Spesimen Pada Mesin Bubut. JMEMME (Journal of Mechanical Engineering, Manufactures, Materials and Energy). 1 (1): 38-47 


\section{PENDAHULUAN}

Mesin bubut adalah suatu mesin perkakas yang digunakan untuk memotong benda yang diputar. Bubut sendiri merupakan suatu proses pemakanan benda kerja yang sayatannya dilakukan dengan cara memutar benda kerja kemudian dikenakan pada pahat yang digerakkan secara translasi sejajar dengan sumbu putar dari benda kerja. Prinsip kerja dari mesin bubut adalah gerak potong yang dilakukan oleh benda kerja yang berputar (bergerak rotasi) dengan gerak makan oleh pahat yang bergerak translasi dan dihantarkan pada benda kerja. Gerakan putar dari benda kerja disebut gerak potong relatif dan gerakkan translasi dari pahat disebut gerak umpan.

Pada dasarnya keausan pahatakan menentukan batasan umur pahat. Pemilihan bentuk/jenis pahat, material benda kerja dan kondisi pemotongan yang tidak tepat akan berpengaruh terhadap karakteristik pahat tersebut. Oleh karena itu perlu diketahui pengaruh pahat potong, material benda kerja, dan kondisi pemotongan (kecepatan potong, kedalam potong dan gerak makan ) terhadap keausan pahat bubut. Kecepatan potong (cutting speed) tidak dapat dipilih sembarangan, bila kecepatan potong rendah akan memakan waktu dalam mengerjakanya. Bila kecepatan terlalu tinggi pahat akan kehilangan kekerasan (karena panas), pahat cepat aus dan umur pahat pahat pendek harus diganti dengan yang baru, oleh karena itu kecepatan potong dan kedalaman pemakanan harus ditentukan sesuai dengan dimensi karakter benda kerja

Selama proses permesinan berlangsung terjadi interaksi antara pahat dengan benda kerja dimana benda kerja terpotong sedangkan pahat mengalami gesekan. Gesekan antara pahat dan benda kerja ini akan menimbulkan panas yang tinggi. Panas akibat gesekan ini sebagian terbawa oleh geram,sebagian merambat pada pahat dan sebagian lagi mengalir pada sekeliling benda kerja.panas yang timbul tersebut cukup besar dan karena luas bidang kontak relatif kecil maka temperatur pahat,terutama bidang geram dan bidang utamanya akan sangat tinggi. Karena tekanan yang besar akibat gaya pemotongan serta temperatur yang tinggi maka permukaan aktif mata pahat akan mengalami keausan. Untuk itu perlu diketahui parameter pemotongan seperti gaya potong, putaran mesin, dan temperature pemotongan. Tujuan dari tulisan ini adalah untuk merancang dan membangun sebuah alat untuk mengukur parameter pemotongan seperti gaya potong, putaran, dan suhu. 
Proses permesinan merupakan suatu proses untuk menciptakan produk melalui tahapan - tahapan dari bahan baku untuk diubah atau di proses dengan cara - cara tertentu secara urut dan sistematis untuk menghasilkan suatu produk yang berfungsi (Marsyahyo, 2003).

Kekuatan dan kekakuan dari mesin perkakas maupun benda kerja adalah sangat penting untuk mengurangi deformasi yang diakibatkan oleh gaya gaya yang terjadi sewaktu pemotongan, lenturan yang terjadi pada benda kerja ataupun bagian - bagian mesin lainnya akan mengurangi ketelitian dari produk, pengaruh pada gaya - gaya pemotongan akan mempengaruhi ketelitian suatu produk (Kurniawan 2008).

Pada pahat potong, diketahui bahwa resultan gaya terdiri atas tiga komponen dasar, yaitu FT (gaya tangensial/gaya pada kecepatan potong ),FR (gaya radial/gaya pada kedalaman pemotongan ), dan FL (gaya longitudinal/gaya pada pemakanan atau gerak makan ).

Pada proses permesinan yang sedang berlangsung bermacam-macam gaya pemotongan akan terjadi,gaya pemotongan akan mempengaruhi bagus tidaknya suatu produk yang akan di bentuk, oleh karena itu sangat diperlukan adanya alat ukur gaya potong pada proses permesinan, dalam hal ini khususnya pada mesin bubut sehingga kita dapat menganalisa berapa besar gaya yang timbul dan berapa besar gaya yang dibutuhkan untuk memproses suatu material. Elemen dasar dari proses bubut dapat diketahui atau dihitung dengan menggunakan rumus yang dapat diturunkan dengan memperhatikan gambar 2.1, kondisi pemotongan ditentukan sebagai berikut,

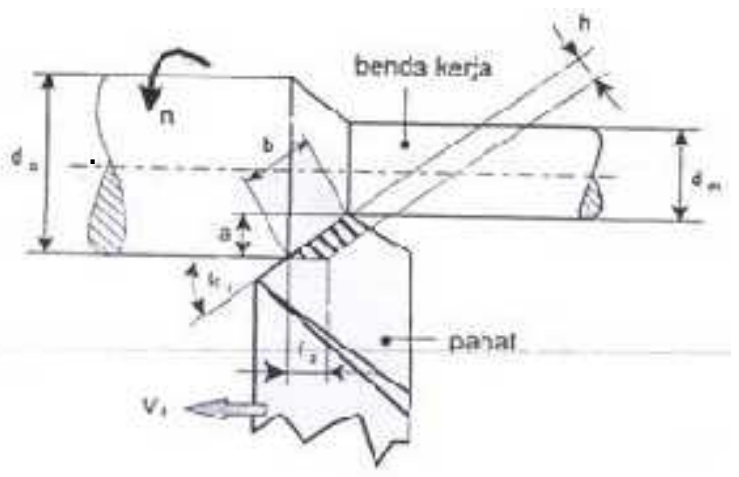

Gambar 1Elemen dasar proses bubut

Elemen dasar dapat dihitung dengan rumus-rumus berikut,

KecepatanPotong :

$V \frac{\pi \cdot d . n}{1000}^{\mathrm{m} / \mathrm{min}}$

$d=(d o-d m) / 2$

Kecepatanmakan :

$V_{f}=f . n \quad \mathrm{~mm}$

Waktu pemotongan :

$t_{c}=l_{t} / v_{f} \quad ; \min$

Kecepatan penghasilan geram : $Z=A . V$

$A=f . a \quad \mathrm{~mm}^{2}$ 


$$
Z=f \cdot a . v^{\mathrm{cm}^{3} / \mathrm{min}}
$$

\section{METODE PENELITIAN}

\section{Diagram Alir Rancang Bangun}

Berikut ini adalah diagram alir dalam perancangan instrument mesin bubut yang ditunjukkan pada Gambar 2 dibawahini.

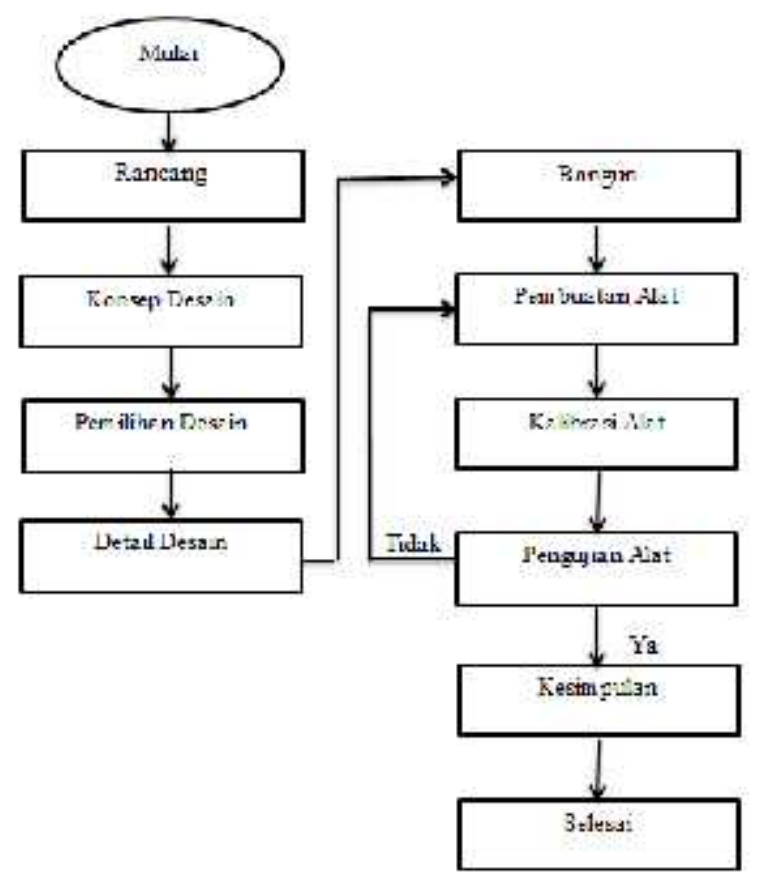

Gambar 2 Diagram rancangbangun IdentifikasiKebutuhan

Dalamperancangan instrument mesinbubutiniadabeberapakebutuhankons umen yang harusdipenuhiantara lain ialah : (a)Instrument mampu membaca gaya potong. (b)Mampu membaca rpm . (c)Mampu membaca temperatur spesimen. (d)Hasil pengukuran bisa ditampilkan di komputer. (e)Center pahat bisa diatur naik dan turun. (f)Bisa dipasang pahat insert. (g)Bisa digunakan oleh mesin bubut kecil dan mesin bubut besar. (h)Konstruksi instrument kuat. (i)Mudah dirakit. (j)Harga pembuatan terjangkau.

Setelah menyusun identifikasi kebutuhan, kemudian menyusun design requirement and objectives (DR\&O) yang menjabarkan kebutuhan konsumen menjadi spesifikasi produk yang lebih detail.Berikut adalah DR\&O instrument mesin bubut (Gandung ,2013) : (a)Instrument mampu mengukur gaya potong. (b)Hasil pengukuran bisa ditampilkan di komputer dan disimpan di memori komputer. (c)Center pahat bisa diatur tanpa adanya pemberian alas / ganjal pada toolpost. (d)Menggunakan pahat insert, yang dapat diganti - ganti. (e)Penyetingan instrument lebihkurang 30 menit. (f)Hargapembuatankurangdari 10 juta.

\section{KonsepDesain}

Pada konsep pertama sensor loadcell dipasang pada celah pengikat pahat, konsep ini dinilai terlalu sederhana dan tidak bisa untuk setting centrenya seperti terlihat pada Gambar 3 dibawah ini.

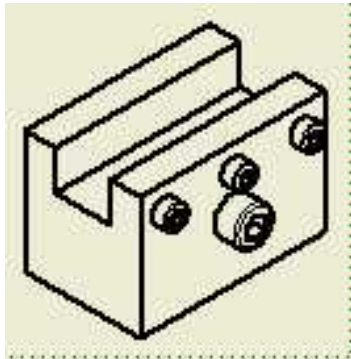

Gambar 3.Konsep pertama pemegang loadcell dan pahat 
Pada konsep kedua harus dibuatkan tool post dan rumah pahat ,dikarenakan tool post standarnya mempunyai ukuran tersendiri , oleh sebab itu maka harus dibuatkan tool post untuk pemegang rumah pahat, konsep ini dinilai terlalu memakan biaya dan penggunaanya cukup susah untuk mendapatkan center , seperti terlihat pada Gambar 4 dibawah ini.

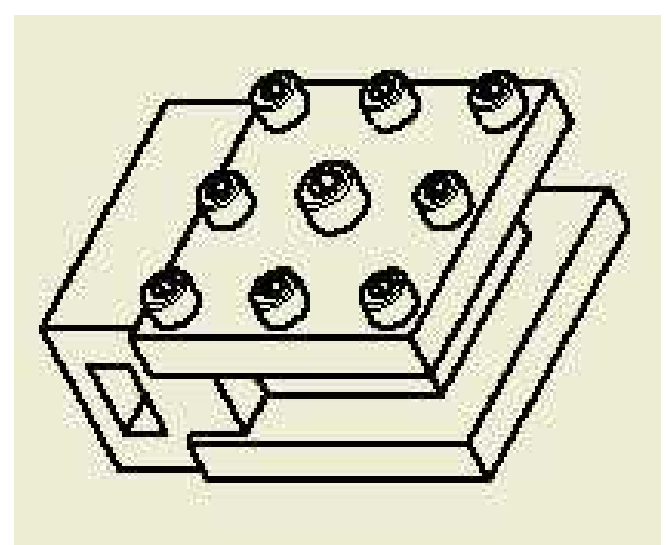

Gambar4. Konsep kedua pemegang loadcell dan pahat

Berikut ini adalah konsep ketiga3, konsep ini dinilai bagus dan mudah digunakan oleh siapa saja yang ingin menggunakannya, konsep ini bisa digunakan pada mesin bubut kecil ataupun besar ,untuk konsep ini cukup mudah dalam menyetting senternya seperti terlihat pada Gambar5.

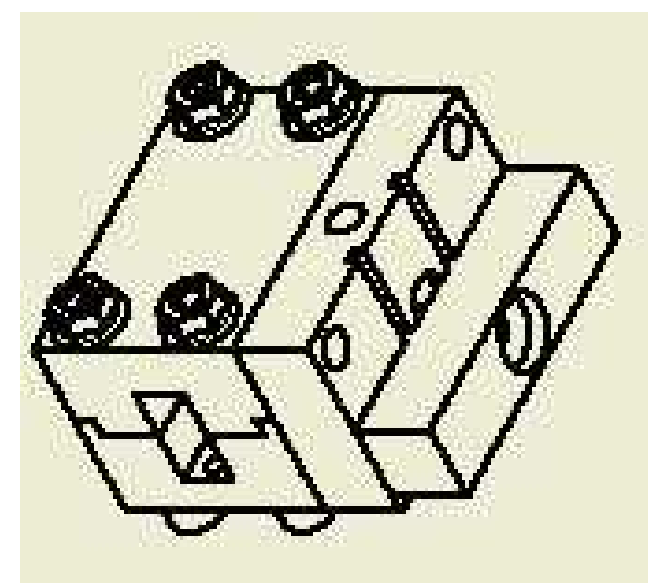

Gambar5 Konsep 3 pemegang loadcell dan pahat

\section{HASIL DAN PEMBAHASAN}

\section{Membuat Setting Center}

Setting center adalah bagian yang berfungsi untuk mengatur center posisi pahat, setting center dibuat dengan menggunakan dua jalur untuk naik dan turun seperti terlihat pada Gambar 6 dibawah ini :

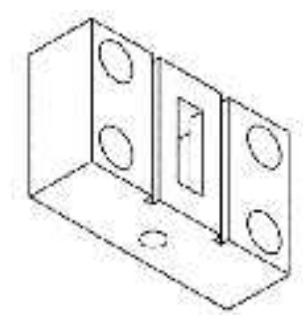

Gambar 6. DesainSetting Center

Meratakan permukaan benda dengan ukuran yang direncanakan yaitu tebal 25 $\mathrm{mm}$, panjang $80 \mathrm{~mm}$, dan tinggi $50 \mathrm{~mm}$ hasil yang diperoleh sesuai dengan ukuran yang direncanakan karena mata milling yang digunakan berdiameter besar dan proses pengerjaannya hanya dengan sekali jalan seperti yang terlihat pada Gambar 7 proses perataan permukaan benda. 

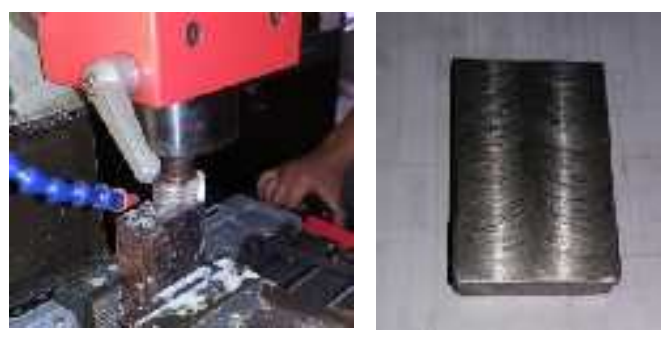

Gambar.7 Proses Perataan Permukaan Benda

Membuat jalur naik turun dengan ukuran lebar $5 \mathrm{~mm}$ dan kedalaman $3 \mathrm{~mm}$ seperti ukuran yang direncanakan, pada proses ini hasil pembuatan kedalaman tidak sesuai dengan ukuran yang telah di rencanakan karena melihat hasil kedalaman $3 \mathrm{~mm}$ sepertinya terlalu sedikit untuk dudukan pemegang toolpost oleh karena itu kedalaman diubah menjadi 5 $\mathrm{mm}$ agar pemegang toolpost benar - benar duduk pada rumah setting senter seperti terlihat pada Gambar 8 proses pembuatan alur dibawah ini. Membuat dudukan baut setting senter dengan ukuran lebar $20 \mathrm{~mm}$ dan kedalaman $20 \mathrm{~mm}$ seperti pada ukuran yang direncanakan, pada proses ini hasil pada sisi sudut yang seharusnya siku tidak sesuai dengan hasil yang dibuat, hasil yang dibuat adalah sisi sudut yang berradius dikarenakan proses pembuatan menggunakan milling. Membuat empat lubang baut dengan mata bor $8 \mathrm{~mm}$ kedalaman $25 \mathrm{~mm}$ untuk badan baut dan 13,5 mm untuk dudukan kepala baut kemudian membuat lubang baut setting naik atau turun sepanjang $50 \mathrm{~mm}$, hasil dari pada proses pembuatan lubang ini sesuai dengan ukuran yang di rencanakan karena sebelum pembuatan dilakukan pengukuran yang disesuaikan pada desain seperti yang dapat kita lihat pada gambar 4.5 sebagai berikut.

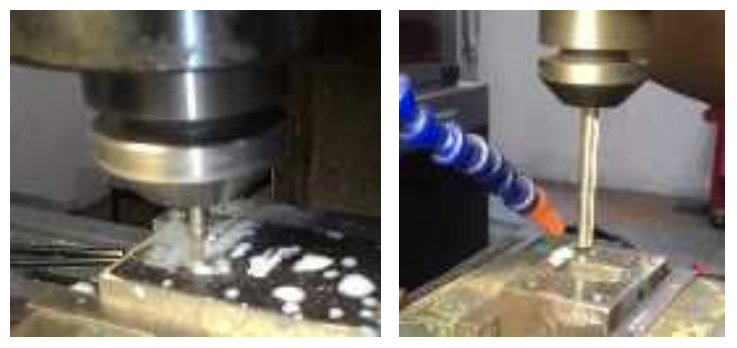

Gambar 8 Proses pembuatan alur dibawah

\section{Membuat Pemegang Setting Center}

Pemegang setting senter berfungsi sebagai pegangan pada toolpost mesin bubut dengan tebal $20 \mathrm{~mm}$ dan lebar 25 mm dan $3 \mathrm{~mm}$ untuk untuk dudukan naik dan turun pada setting senter kemudian lubang tengah $10 \mathrm{~mm}$ seperti terlihat pada Gambar 9 dibawah ini .

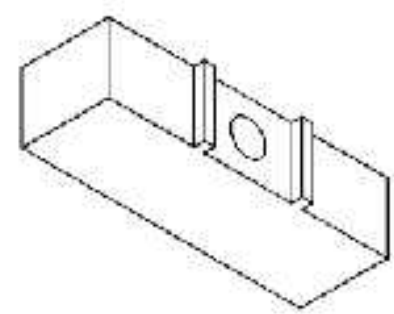

Gambar 9.Desain pemegang setting center

Meratakan permukaan benda dengan ukuran yang direncanakan yaitu panjang $80 \mathrm{~mm}$, tebal $20 \mathrm{~mm}$ dan tinggi $25 \mathrm{~mm}$, hasil yang diperoleh sesuai dengan ukuran yang direncanakan, dikarenakan diameter mata milling yang besar sehingga proses 
pengerjaan sekali jalan seperti terlihat pada Gambar 10 proses pembuatan pemegang setting center.
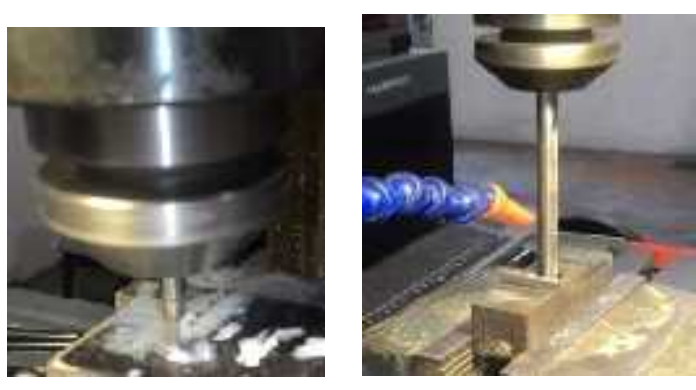

Gambar.1oProses pembuatan pemegang setting center

Membuat Rumah Loadcell

Rumah loadcell berfungsi sebagai dudukanloadcell dibuat desain, seperti terlihatpada Gambar 11 dibawah ini.

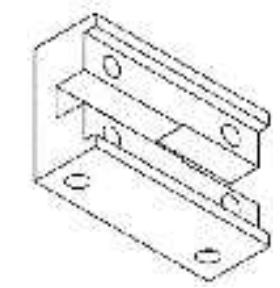

Gambar 11 Desain rumah loadcell

Meratakana permukaan benda untuk mendapatkan ukuran yang telah ditentukan yaitu dengan ukuran panjang $80 \mathrm{~mm}$, tebal $28 \mathrm{~mm}$ dan tinggi $53 \mathrm{~mm}$, dengan hasil ukuran yang sesuai pada desain karena proses pengerjaan hanya sekali jalan seperti terlihat pada Gambar 12
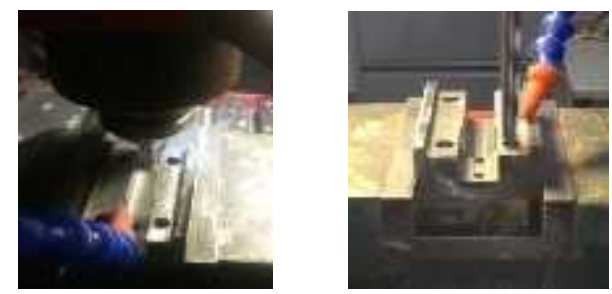

Gambar 12 proses pembuatan rumah loadcell
Membuat dudukan rumah pahat dengan ukuran yang direncanakan yaitu $43 \mathrm{~mm}$ memakai mata milling $41 \mathrm{~mm}$ kemudian membuat dudukan loadcell dengan lebar $13 \mathrm{~mm}$, kedalaman $13 \mathrm{~mm}$ dengan mata milling $10 \mathrm{~mm}$, pada proses ini hasil ukuran sesuia dengan ukuran yang direncanakan. Membuat lubang sesuai ukuran yang direncanakan dengan menggunakan mata bor $8 \mathrm{~mm}$ dengan kedalaman $28 \mathrm{~mm}$ untuk dudukan rumah pahat dan dudukan setting senter dengan kedalaman $7.5 \mathrm{~mm}$, dengan hasil yang berbeda pada lubang, yang diubah menjadi diameter $7 \mathrm{~mm}$ karena pada lubang tersebut akan dibuatkan ulir drat dan dipasangkan baut yang berdiameter $8 \mathrm{~mm}$.

\section{Membuat Rumah Pahat}

Rumah pahat berfungsi sebagaidudukan pahat dibuat sesuai ukuran yang ditentukan seperti terlihat pada gambar 13.

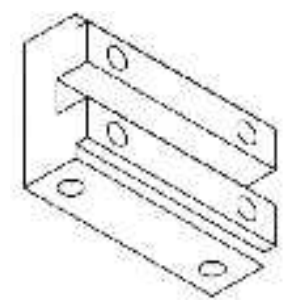

Gambar 13DesainRumah pahat

Meratakan permukaan benda dengan ukuran yang telah direncanakan yaitu dengan panjang $80 \mathrm{~mm}$, lebar $53 \mathrm{~mm}$ dan tebal $27 \mathrm{~mm}$, dengan menggunakan mata 
milling $41 \mathrm{~mm}$ dengan hasil yang sesuai pada ukuran yang telah di rencanakan seperti terlihat pada gambar 4.16 proses perataan permukaan benda Membuat dudukan rumah loadcell dengan ukuran 5 mm pada sisi kiri dan kanan dengan kedalaman $5 \mathrm{~mm}$ memakai mata milling 10 mm dan membuat dudukan pahat dengan lebar $13 \mathrm{~mm}$ dan kedalaman $13 \mathrm{~mm}$ sesuai dengan ukuran yang telah ditentukan, dan dengan hasil yang sesuai pada ukuran yang direncanakan seperti yang terlihat pada Gambar 14 berikut ini.
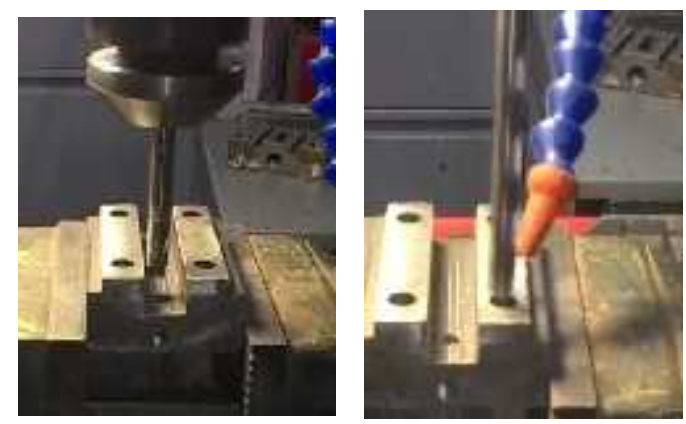

Gambar 14. Proses pembuatanrumah pahat

Membuat lubang dengan menggunakan mata bor $8 \mathrm{~mm}$ dengan kedalaman $28 \mathrm{~mm}$ untuk pengunci pada rumah pahat ke rumah loadcell dan lubang $7 \mathrm{~mm}$ dengan kedalaman $10 \mathrm{~mm}$ untuk pengunci setting center, dengan hasil yang sesuai pada ukuran yang telah ditentukan. Membuat ulir pada lubang $7 \mathrm{~mm}$ untuk pengikat antara rumah pahat.

\section{Proses Perakitan Instrument}

Instrument ini terbagi atas empat komponen yang berbeda, dan untuk perakitannya terbilang cukup mudah berikut ini adalah langkah - langkah dalam perakitan instrument mesin bubut. Pemasangan loadcell pada rumah loadcell atau dudukan loadcell yang dihubungkan dengan 2 baut seperti terlihat pada Gambar15.
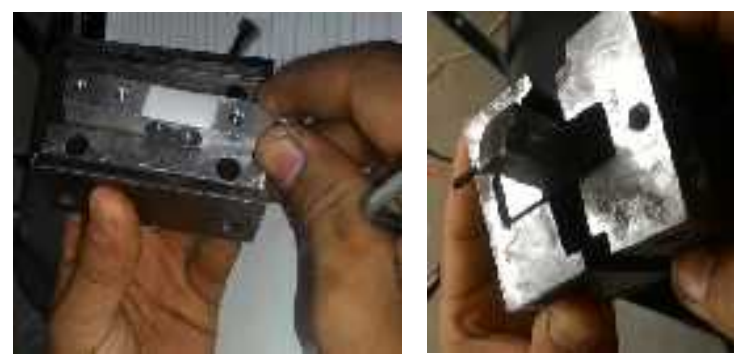

Gambar 15. Proses Perakitan Instrument

\section{Pengujian Instrumen}

Memasang instrumentasi pada penjepit pahat (tool post) mesin bubut dan terlebih dahulu melakukan penyetalan center mata pahat pada kepala lepas (tail stock) dapat dilihat pada gambar 15.Memasang plat sensorputaransensor photoelectriccounter module pada Gambar 16 sebanyak 3 buah pada kepala chuck dengan 3 titik sudut yang berbeda.

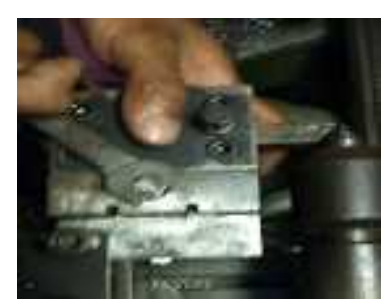

Gambar 16. Menyetel dan memasang intrumenrasi pada penjepit pahat (tool post) 


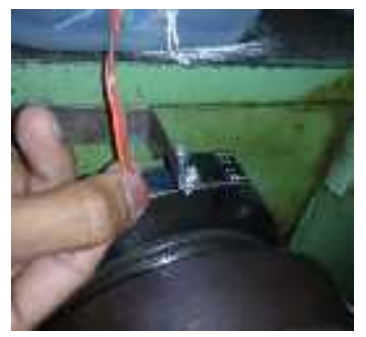

Gambar 17. Memasang 3 buah plat sensor

Memasanng sensor photoelectric counter module pada Gambar 17Menghubungkan sensor photoelectric counter module kerangkaian pada program Arduino pada Menghubungkan rangkaian Arduino pada laptop. seperti Gambar 18.

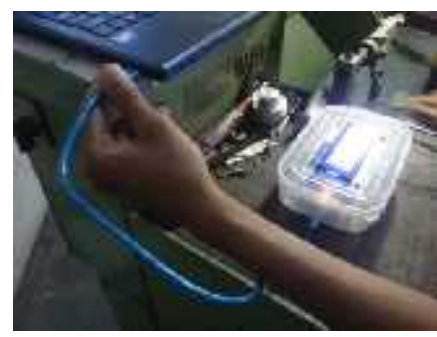

Gambar 18. Menghubungkan rangkaian Arduino

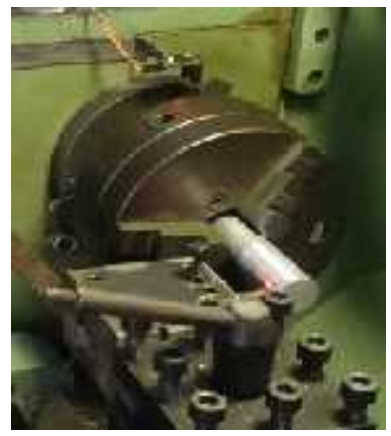

Gambar 19. Memasang specimen pada chuck

\section{HasilPengujian}

Pengujian instrument ini dilakukan di mesin bubut laboratorium teknik mesin
UMSU,dengan menggunakan 6 material yang berbeda dengan ukuran diameter 25 mm x $100 \mathrm{~mm}$ dan menggunakan 2 pahat yang berbeda, yaitupahat DCGT dan DCMT. Parameter permesinan yang digunakan adalah dengan putaran mesin yang bervariasi $90 \mathrm{rpm}, 110 \mathrm{rpm}, 155 \mathrm{rpm}$, dan $190 \mathrm{rpm}$, dan kedalaman potong (depth of cut) yang konstan, yaitu 0,3 mm

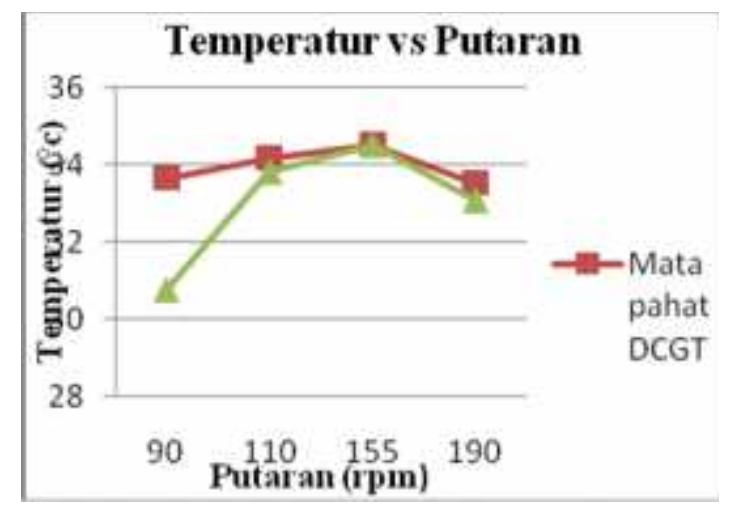

Gambar 20 Grafik Temperatur terhadap Putaran

Pada Gambar 20 dapat diketahui grafik hasil pengujian pembubutan dengan mata pahat DCMT dan DCGT terhadap spesimen Aluminium murni(al 1100) dengan kedalaman pemakanan (Deft of cut) sebesar $0,3 \mathrm{~mm}$ dan variasi putaran 90,110,155, dan190 rpm. Diketahui pada putaran $90 \mathrm{rpm}$ dengan mata pahat DCMT di dapat temperatur pemotongan sebesar $30,76{ }^{\circ} \mathrm{C}$ sedangkan pada mata pahat DCGT temperatur pemotongan sebesar 33,64 ${ }^{\circ} \mathrm{C}$.Pada putaran $190 \mathrm{rpm}$ temperatur pemotongan dengan mata pahat DCMT didapat sebesar $33,08 \quad{ }^{\circ}$ sedangkan dengan penggunaan mata pahat DCGT di 
dapat temperatur pemotongan sebesar $33,52{ }^{\circ} \mathrm{c}$, dapat disimpulkan pada pahat DCGT akan lebih dulu mengalami pemuaian, karena penggunaan pahat DCGT mengalami panas yang lebih besar dari pada pahat DCMT.

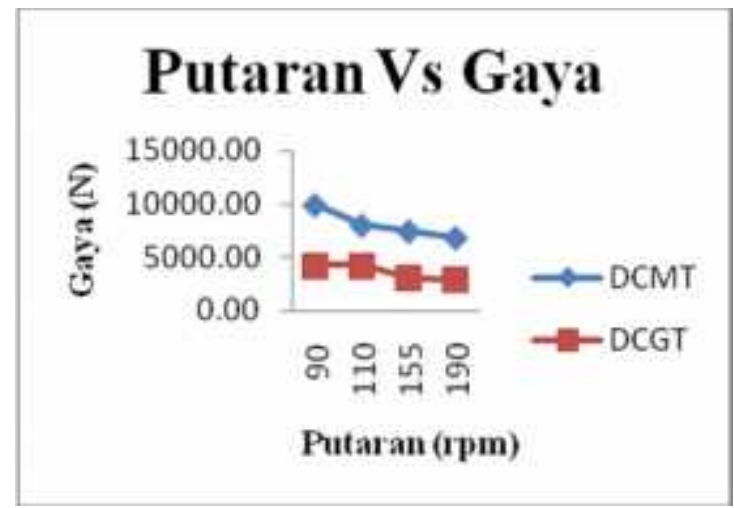

Gambar 21. Grafik Putaran Vs Gaya

Dari hasil pegujian pada spesimen aluminium murrni (al 1100) pada Gambar 19 dengan pemakanan kedalaman (depth of cut) sebesar $0,3 \mathrm{~mm}$ dan variasi putaran 90,110,155, dan190 rpm dapat diketahui pada mata pahat DCMT lebih besar gaya potong yang terjadi dibandingkan dengan pahat DCGT. Gaya potong yang dihasilkan pada mata pahat DCMT sebesar 9909,96 N dengan putaran $90 \mathrm{rpm}$ dan pada putaran 190 rpm pahat DCMT mendapat gaya sebesar 6825,01 N. dapat disimpulkan bahwa pada putaran rendah gaya potong yang terjadi akan lebih besar, seperti yang dapat dilihat pada Gambar21.

\section{SIMPULAN}

Pada rancang bangun instrument ini didapatkan beberapa kesimpulan yaitu :

Bahwa alat yang dirancang telah selesai dengan rancangan spesifikasi dan bekerja dengan baik seperti ditunjukkan pada hasil pengujian.

Instrument ini mampu mengukur gaya potong, kecepatan dan temperature specimen pada proses pembubutan yang sedang berlangsung secara bersamaan .

\section{DAFTAR PUSTAKA}

Kurniawan. 2008. Study Tentang Cutting Force Mesin Bubut (Desain Dynamometer Sederhana)Surakarta: $\quad$ SkripsiProgram Sarjana Universitas Muhammadiyah Surakarta.

Marsyahyo,Eko, 2003, Mesin Perkakas Pemotongan Logam, Toga Mas, Malang.

Purwoko,G.S. 2013. Rancang Bangun Dynamometer Untuk Pengukuran Gaya Potong Mesin Bubut.Surakarta: Program Sarjana Universitas Sebelas Maret.

Taufiq Rochim, 1993,Teori \& Teknologi Proses Permesinan. Higher Education Development Support Project. 